\title{
ESTADO, GOVERNO E PARLAMENTO: REFLEXÕES SOBRE PROJECTOS CONSTITUCIONAIS EM PORTUGAL (1911)
}

\section{STATE, GOVERNMENT AND PARLIAMENT: REFLECTIONS ON CONSTITUTIONAL PROJECTS IN PORTUGAL (1911)}

\author{
Ernesto Castro Leal \\ Universidade de Lisboa
}

\begin{abstract}
SUMÁRIO: I.- INTRODUÇÃO; II.- MANIFESTO E PROGRAMA DO PARTIDO REPUBLICANO PORTUGUÊS; III.- CONSTITUIÇÃO POLİTICA DA REPÚBLICA PORTUGUESA; IV.- PROJECTO DA COMISSÃO DA CONSTITUIÇÃO; V.INDICAÇÕES PARA A CONSTITUIÇÃO POLÍTICA DA REPÚBLICA PORTUGUESA; VI.- BASES PARA A CONSTITUIÇÃO POLÍTICA DA REPÚBLICA PORTUGUESA; VII.- CONSTITUIÇÃO OU CÓDIGO FUNDAMENTAL DA REPÚBLICA PORTUGUESA; VIII.- BASES PARA A CONSTITUIÇÃO DA REPÚBLICA PORTUGUESA; IX.- PROJECTO CONSTITUCIONAL; X.- PROJECTO DA CONSTITUIÇÃO PORTUGUESA; XI.-CONCLUSÕES.
\end{abstract}

Resumo: O objectivo principal deste artigo é discutir, numa perspectiva históricopolítica e constitucional, sete Projectos Constitucionais apresentados em 1911 à Assembleia Nacional Constituinte Portuguesa. Nesses projectos surgem divergências em relação ao que será consagrado na Constituição de 1911, quanto à forma de Estado, à forma de governo e ao sistema de governo. Apresenta-se uma visão teórica sobre esses três tópicos e assinala-se as propostas alternativas de modelo institucional republicano.

\begin{abstract}
The main goal of this article is to discuss, in a historical, political and constitutional point of view, seven of the Constitutional projects presented to the Portuguese National Constitutional Assembly in 1911. Several divergences emerge about these projects, mainly due to the different opinions regarding what should and what should not be established in the Constitution of 1911, its form of State, form of Government and its system. A theoretical vision is also presented on these three topics, highlighting the republican institutional model's alternative proposals.
\end{abstract}

Palavras-chave: I República Portuguesa, Republicanismo, Modelos de República, Constituição de 1911, Projectos Constitucionais de 1911

Keywords: Portuguese First Republic, Republicanism, Republic models, Constitution of 1911, Constitutional projects of 1911

\section{INTRODUÇÃO}

O objectivo deste texto é discutir, dentro de uma perspectiva históricopolítica e jurídico-constitucional, sete Projectos Constitucionais apresentados em 
1911 à Assembleia Nacional Constituinte Portuguesa, onde se manifestaram divergências em relação ao que seria consagrado na Constituição Política da República Portuguesa, mostrando a existência de várias tradições filosóficas e ideológico-politicas no interior do republicanismo português que continuaram a existir durante o regime político da I República Portuguesa ${ }^{1}$ : a) Projecto da Comissão da Constituição; b) Projectos de cinco deputados; c) Projecto do Grémio Montanha (nome profano da respectiva loja maçónica). Para a análise comparada destes sete Projectos Constitucionais, seleccionaram-se três tópicos principais sobre o Estado Contemporâneo ${ }^{2}$, discutidos na ciência política, na ciência jurídica e na história das ideias: forma de Estado, forma de governo e sistema de governo.

Após uma visão geral teórica sobre esses três tópicos e a sua consagração no Manifesto e Programa de 1891 do Partido Republicano Português e na Constituição de 1911, pretende-se surpreender a diversidade constante nos sete Projectos Constitucionais republicanos e, em particular, assinalar as formulações jurídico-constitucionais sobre esses três tópicos que não obtiveram acolhimento na Constituição de 1911.

A base empírica sujeita a análise crítica é a seguinte: Projecto da Comissão da Constituição (relator: Sebastião de Magalhães Lima); Indicações para a Constituição Política da República Portuguesa (Teófilo Braga); Bases para a Constituição Politica da República Portuguesa (António Machado Santos); Constituição ou Código Fundamental da República Portuguesa (Fernão BotoMachado); Bases para a Constituição da República Portuguesa (Manuel Goulart de

1 Para o enquadramento histórico e jurídico-político, cf. Fernando Catroga, O Republicanismo em Portugal. Da formação ao 5 de Outubro de 1910, Faculdade de Letras da Universidade de Coimbra, Coimbra, 1991, pp. 257-321; Id., "O Republicanismo Português (Cultura, história e politica)", Revista da Faculdade de Letras - História, III série, vol. 11, 2010, pp. 95-119; J. J. Gomes Canotilho, Direito Constitucional e Teoria da Constituição, $6^{\mathrm{a}}$ ed., Almedina, Coimbra, 2002, pp. 162-177; Jorge Miranda, Manual de Direito Constitucional, $7^{\mathrm{a}}$ ed., Coimbra Editora, Coimbra, 2003, vol. I, pp. 289-298; Id., "A Assembleia Constituinte e a Constituição de 1911 - Um relance geral”, en Jorge Miranda, Alexandre Sousa Pinheiro e Pedro Lomba (edit.), A Assembleia Constituinte e a Constituição de 1911. Catálogo de Exposição, Assembleia da República/Centenário da República, Lisboa, 2011, pp. 11-51; Alexandre Sousa Pinheiro, "Análise dos debates travados na Assembleia Constituinte de 1911. Projectos de Constituição apresentados e texto final da Constituição", ibid., pp. 53-145; Ernesto Castro Leal, Partidos e Programas. O campo partidário republicano português (1910-1926), Imprensa da Universidade de Coimbra, Coimbra, 2008; Id., " $A$ Constituição de 1911. Republicanismo e direitos fundamentais”, en Ana Maria Belchior (edit.), As Constituições Republicanas Portuguesas. Direitos fundamentais e representação politica (19112011), Mundos Sociais, Lisboa, 2013, pp. 17-26; Fernando Farelo Lopes, "A Constituição 'eficiente'. Forma de governo, sistema eleitoral e sistema de partidos na I República Portuguesa”, ibid., pp. 27-42; Paulo Ferreira da Cunha, O Essencial sobre a I República e a Constituição de 1911, Imprensa Nacional-Casa da Moeda/Centenário da República, Lisboa, 2011; António Manuel Hespanha, "O positivismo sociológico e o institucionalismo", en António Manuel Hespanha, Cultura Juridica Europeia. Sintese de um milénio, Almedina, Coimbra, 2012, pp. 460-478; Miriam Halpern Pereira, "A $1^{a}$ República e o Sufrágio em Portugal: o debate de 1911 em perspectiva diacrónica", Historia Constitucional, $\mathrm{n}^{\circ}$ 15, 2014, pp. 509-527. http://www.seminariomartinezmarina.com /ojs/index.php/historiaconstitucional/article/view/411/370; Id., A Primeira República. Na fronteira do liberalismo e da democracia, Gradiva, Lisboa, 2016.

2 Norberto Bobbio, "Estado", en Ruggiero Romano (edit.), Enciclopédia Einaudi, Imprensa Nacional-Casa da Moeda, Lisboa, 1989, vol. 14, pp. 215-275; Gustavo Gozzi, "Estado Contemporâneo", en Norberto Bobbio, Nicola Matteucci e Gianfranco Pasquino (edit.), Dicionário de Politica, 12a ed., Universidade de Brasília/Dinalivro, Brasília, 2004, vol. 1, pp. 401-409. 
Medeiros); Projecto Constitucional (Tomás Cabreira); e Projecto da Constituição Portuguesa (Grémio Montanha).

Os Projectos Constitucionais individuais foram subscritos por Teófilo Braga (formado em Direito mas com uma carreira de professor do Curso Superior de Letras, dedicando-se principalmente à Literatura, História, Filosofia e Sociologia), António Machado Santos (oficial de Marinha/Administração Militar), Fernão Boto-Machado (solicitador), Manuel Goulart de Medeiros (oficial do Exército/Artilharia) e Tomás Cabreira (oficial do Exército/Engenharia e professor da Escola Politécnica de Lisboa). O Projecto Constitucional do Grémio Montanha foi escolhido porque o Projecto Constitucional de António Machado Santos, membro da Loja Montanha, difere no modelo proposto, concluindo-se que aquele não vincula todos os seus membros. É provável que alguns tenham tido apoio de juristas para a elaboração dos seus projectos.

Partindo de diversas sistematizações, nas áreas da ciência política e da ciência jurídica, sobre os conceitos de formas de Estado, de formas de governo e de sistemas de governo, conclui-se que, excluindo a ordenação jurídico-política consistente da Constituição de 1911 e o menor grau de consistência do Projecto da Comissão da Constituição, os articulados jurídico-políticos dos outros seis Projectos Constitucionais republicanos são imperfeitos, por vezes contraditórios, face às características dominantes desses conceitos.

Em relação à forma de Estado, que tem a ver, segundo o constitucionalista Giancarlo Rolla, com "as relações que se instauram entre o poder político e o território"3, tipificam-se habitualmente duas: a) Estado unitário (Estado homogéneo ou simples), que pode ser centralizado, descentralizado ou regional, onde "há apenas um poder político dotado de autoridade constituinte em todos o território..., que revestirá também a qualidade de poder soberano"; b) Estado federal ou União Real (Estado composto ou integrado), onde "há vários poderes politicos dotados de autoridade constituinte no território, poderes esses que se articulam em distintos niveis territoriais"4.

A forma de governo, na opinião do constitucionalista Jorge Reis Novais, exprime a "consideração do tempo e modo de sucessão na chefia do Estado..., distinguindo-se em função da via hereditária ou não hereditária, de sucessão (monarquia, república)" 5 . Nos Projectos Constitucionais analisados está obviamente consagrada a República e nalguns existe uma precisão denominativa com significado ideológico-político (por exemplo, República democrática, República democrática parlamentar ou República federal democrática).

Face ao sistema de governo (parlamentar, presidencial, directorial ou convencional), a classificação adoptada será genérica, devedora da intensão política geral dos redactores dos Projectos Constitucionais, dado que se verifica várias incoerências face a elementos essenciais dessas tipologias políticas.

3 José Melo Alexandrino, Lições de Direito Constitucional, Associação Académica da Faculdade de Direito de Lisboa, Lisboa, 2015, vol. I, p. 99.

4 José Melo Alexandrino, Lições de Direito Constitucional, op. cit., vol. I, p. 100; Justo G. Beramendi, La Historia Politica. Algunos Conceptos Básicos, Tórculo, Santiago de Compostela 1999, pp. 91-92.

5 José Melo Alexandrino, Lições de Direito Constitucional, op. cit., vol. I, p. 147. 
Seguindo vários autores, em particular o constitucionalista José Melo Alexandrino, que sistematizaram os principios de base desses sistemas de governo, elencam-se algumas características essenciais:

a) sistema de governo parlamentar: o Governo é formado a partir da representação parlamentar; o Governo depende apenas da confiança do Parlamento e é perante ele politicamente responsável; apagamento da posição do Chefe de Estado, exigindo-se a refenda ministerial (assinatura de um ministro) dos seus actos políticos; separação ou dualidade entre Chefe de Estado e Chefe do Governo; pode existir ou não o poder de dissolução do Parlamento conferido ao Chefe de Estado; no sistema de governo parlamentar de assembleia afirma-se um ascendente do Parlamento, que elege e destitui o Chefe de Estado, não existindo o poder de dissolução do Parlamento e o Governo não dispõe de poderes efectivos de intervenção junto do Parlamento ${ }^{6}$.

b) sistema de governo presidencial: o Chefe de Estado é eleito habitualmente por sufrágio directo universal; o Chefe de Estado é também Chefe do Governo e nomeia livremente os secretários de estado; existe uma rigorosa separação entre o Chefe de Estado e o Parlamento e não respondem politicamente um perante o outro; no sistema de governo presidencial perfeito (Estados Unidos da América), para manter o equilíbrio do sistema há um conjunto de freios (controlos) e contrapesos (checks and balances); no sistema de governo presidencial adulterado (América Latina), o Chefe de Estado é auxiliado por ministros responsabilizados e os actos do Chefe de Estado são por eles referendados ${ }^{7}$.

c) sistema de governo directorial: concepção rígida de separação de poderes; o poder executivo é exercido por um órgão colegial (Conselho Federal ou Directório); o Parlamento é bicameral, com uma representação nacional (Conselho Nacional) e outra representação dos estados (Conselho dos Estados); não há responsabilidade política entre os poderes executivo e legislativo e ambos não podem ser demitidos mutuamente ${ }^{8}$.

d) sistema de governo convencional: repúdio pela separação e pelo equilíbrio de poderes; predomínio exclusivo do Parlamento, sem contrapesos; criação de um órgão político representativo único (Corpo Legislativo), unicameral, que elege um Conselho Executivo dele totalmente dependente para executar as leis e orientar a administração pública; vigorou durante a Convenção Nacional republicana (França), entre 1792 e $1795^{9}$.

6 José Melo Alexandrino, Lições de Direito Constitucional, op. cit., vol. I, pp. 157-159; Marcello Caetano, Manual de Ciência Politica e Direito Constitucional, $6^{\mathrm{a}}$ ed. revista e ampliada por Miguel Galvão Teles, Almedina, Coimbra, 1991, vol. I (reimpressão), pp. 366-368; Gianfranco Pasquino, Curso de Ciência Política, Principia, Cascais, 2002, pp. 244-247.

7 José Melo Alexandrino, Lições de Direito Constitucional, op. cit., vol. I, pp. 159-160; Marcello Caetano, Manual de Ciência Politica e Direito Constitucional, op. cit., vol. I, pp. 368-371; Gianfranco Pasquino, Curso de Ciência Política, op. cit., pp. 238-241.

8 José Melo Alexandrino, Lições de Direito Constitucional, op. cit., vol. I, p. 161; Jorge Miranda, Manual de Direito Constitucional, op. cit., vol. I, pp. 199-200.

\footnotetext{
9 Jorge Miranda, Manual de Direito Constitucional, op. cit., vol. I, p. 163; Ivo Miguel Barroso, “O sistema de governo convencional. Conceito e alicerces filosóficos, génese histórica e experiências constitucionais", O Direito, n . III, 2011, pp. 615-656; Marcello Caetano, Manual de Ciência Politica e Direito Constitucional, op. cit., vol. I, pp. 94-96, 364.
} 


\title{
II. MANIFESTO E PROGRAMA DO PARTIDO REPUBLICANO PORTUGUÊS
}

O Manifesto e Programa de 11 de janeiro de 1891 do Partido Republicano Português vigorou até à Revolução republicana de 5 de outubro de 1910, apesar de se exprimirem várias correntes de opinião ideológicas e facções políticas dentro do histórico Partido Republicano Português, formado a partir do Congresso Republicano de junho de 1883. Essas divergências manifestaram-se dentro da Assembleia Nacional Constituinte de 1911 e estiveram na origem do novo sistema de partidos políticos criado entre final de 1911 e início de $1912^{10}$. A pluralidade ideológico-política dentro do Partido Republicano Português foi rememorada pelo republicano histórico Manuel Brito Camacho em 1932, dois anos antes da sua morte, com assinalável rigor:

\begin{abstract}
"Havia republicanos federalistas e unitários; parlamentaristas e presidencialistas; conservadores e liberais; descentralizadores na ordem administrativa e centralizadores até à tutela do município. Com respeito às relações do Estado com a Igreja [Católica], havia os partidários do regime concordatório, mantendo a Igreja [Católica], senão sob tutela, no menos sob a imediata e directa fiscalização do Estado, e havia os que reclamavam um regime de separação como veio a decretá-lo, mais tarde a França, sem renunciar à supremacia do poder civil"11.
\end{abstract}

Neste Manifesto e Programa ${ }^{12}$ não surge uma nítida configuração do modelo institucional republicano. A forma de Estado seria federal, a forma de governo republicana, em regime administrativo descentralizador com autonomia municipal e administração civil das províncias ultramarinas, e deduz-se um sistema de governo parlamentar (de assembleia).

Os representantes do poder legislativo eram eleitos por sufrágio universal e directo, com representação das minorias, e tinha dois níveis territoriais, evidenciando um organicismo administrativo (municipios e províncias): a) a Federação de Municípios, que agregava representantes dos municípios, legislava em Assembleias Provinciais sobre todos os actos relacionados com a segurança, a economia e a instrução provincial, dependendo nas relações mútuas da homologação da Assembleia Nacional; b) a Federação de Provincias, que agregava representantes das provincias, legislava em Assembleia Nacional, sancionava as determinações de interesse geral das Assembleias Provinciais e assegurava a autonomia e integridade da Nação. Nota-se uma forte inserção do sufrágio universal, quer em sede de "igualdade na formação da lei", quer em sede das "liberdades politicas, ou de garantia".

Quanto ao poder executivo, denominado de Poder Ministerial, os seus representantes eram eleitos pela Assembleia Nacional em delegação temporária, especializando-se a acção do Presidente nas relações gerais do Estado (o Presidente da Assembleia Nacional era portanto o Chefe de Estado), e dividia-se

10 Ernesto Castro Leal, Partidos e Programas. O campo partidário republicano português (19101926), op. cit., pp. 15-62; Id., Manifestos, Estatutos e Programas Republicanos Portugueses (18731926). Antologia crítica, Imprensa Nacional-Casa Moeda/Biblioteca Res Publicana/Centenário da República, Lisboa, 2014, pp. 136-354.

11 A Lucta, no 5498, 2 de outubro de 1932, p. 1.

12 Ernesto Castro Leal, Partidos e Programas. O campo partidário republicano português (19101926), op. cit., pp. 143-149; Id., Manifestos, Estatutos e Programas Republicanos Portugueses (1873-1926). Antologia critica, op. cit., pp. 56-65. 
em "três grandes ramos" (Ministérios): Segurança Pública (Força Armada de terra e mar; Polícia civil e fiscal; Justiça e Penalidade; Garantias individuais; Relações internacionais), Educação Pública (Instrução elementar, científica e técnica; Relações culturais; Belas-Artes; Salubridade; Assistência; Recompensas cívicas) e Economia Pública (Agricultura; Indústria, Comércio e Navegação; Concessões de obras; Correios e Telégrafos; Arrecadação de impostos; Estatística e Contabilidade geral). Não há alusão a um Chefe do Governo.

Sobre o poder judicial, estabeleciam-se Juízes de Conciliação, Preparação, Arbitragem e Revisão; o Juízo Cível (singular, colectivo e especial); e o Juízo Criminal, Policial e Administrativo. Previam-se tribunais especiais de medicina legal.

\section{CONSTITUIÇÃO POLÍTICA DA REPÚBLICA PORTUGUESA}

A Constituição Politica da República Portuguesa de 1911 acolheu um modelo constitucional sob a forma de Estado unitário e a forma de governo a "república" (artigo $1^{\circ}$ ) - no normativo sobre os crimes de responsabilidade, alude-se ao crime contra o "regime republicano democrático" (artigo $55^{\circ}$ ), precisando-se assim a natureza da república -, em regime administrativo descentralizador (exercício do referendo local), incluindo as províncias ultramarinas ("leis especiais adequadas ao estado de civilização de cada uma delas"), com referência a poderes distritais (distritos) e municipais (municipios), deliberativos e executivos (artigos $66^{\circ}$ e $67^{\circ}$ ), e o sistema de governo parlamentar (de assembleia) (artigo 26 ${ }^{\circ}$, com bicameralismo do Congresso da República (Câmara de Deputados e Senado) (artigo $7^{\circ}$ ), sendo paritária a iniciativa legislativa das duas câmaras, com predomínio da Câmara de Deputados, visto lhe competir privativamente a iniciativa sobre impostos ou sobre a discussão das propostas feitas pelo poder executivo.

O constitucionalista J. J. Gomes Canotilho caracteriza esse sistema de governo como "(1) regime monístico - dado que ao Parlamento é conferido um amplo poder de controlo político sobre o governo, e ao Presidente da República nem sequer era concedido (na redacção inicial) o poder de dissolução das câmaras [só consagrado na lei de revisão de 1919]. (2) governo de assembleia porque não podendo ser dissolvido antes do termo constitucionalmente préfixado, o Congresso era o único órgão que, em teoria, podia condicionar decisivamente as directivas politicas da república democrática"13. No mesmo sentido, o constitucionalista Jorge Miranda tipifica-o como um "sistema parlamentar de assembleia ou, noutra perspectiva, sistema parlamentar atípico, por o Presidente não ter poder de dissolução, nem de veto, e o Congresso ter poder de destituição"14.

A Constituição de 1911 inicia-se com um pequeno preâmbulo, através do qual a Assembleia Nacional Constituinte afirmava, radicada na tradição do messianismo laico republicano (prometeico), a "sua confiança inquebrantável nos superiores destinos da Pátria, dentro de um regime de liberdade e justiça". Apenas se alude genericamente que o "território da Nação Portuguesa é o

\footnotetext{
13 J. J. Gomes Canotilho, Direito Constitucional e Teoria da Constituição, op. cit., pp. 164-165.

14 Jorge Miranda, Manual de Direito Constitucional, op. cit., vol. I, p. 295.
} 
existente à data da proclamação da República" (artigo $2^{\circ}$ ), deixando-se em aberto a controversa divisão de Portugal continental em provincias, que, como se verificará, teve diversos enunciados nos Projectos Constitucionais analisados. Os três poderes do Estado eram "independentes e harmónicos entre si" (artigo 6), seguindo a matriz histórica do constitucionalismo político liberal. Previa-se a revisão constitucional de dez em dez anos e impedia-se alterações cujo "intuito seja abolir a forma republicana do governo" (artigo $82^{\circ}$ ).

Quanto ao poder legislativo (Congresso da República), os deputados eram eleitos por três anos, sendo o número de três senadores por cada distrito do continente e ilhas e de um senador por cada provincia ultramarina, eleitos por seis anos; as duas eleições far-se-iam através de sufrágio directo a regular por lei especial. O poder executivo era exercido pelo Presidente da República e pelos ministros, sendo um deles o Presidente do Ministério. Até 1915 houve nove Ministérios (Interior; Justiça - Justiça e dos Cultos, desde 1914; Finanças; Guerra; Marinha; Negócios Estrangeiros; Fomento; Colónias; Instrução Pública, desde 1913); os Ministérios não constavam do articulado jurídico-constitucional.

O poder judicial tinha como órgãos o Supremo Tribunal de Justiça e Tribunais de primeira e segunda instância; os titulares de cargos politicos seriam processados e julgados nos tribunais ordinários pelos crimes cometidos; os Tribunais têm a competência de apreciação da constitucionalidade das leis do poder legislativo ou dos diplomas do poder executivo: "O Poder Judicial, desde que, nos feitos submetidos a julgamento, qualquer das partes impugnar a validade da lei ou dos diplomas emanados do Poder Executivo ou das corporações com autoridade pública, que tiverem sido invocados, apreciará sua legitimidade constitucional ou conformidade com a Constituição e princípios nela consagrados" (artigo $\left.63^{\circ}\right)^{15}$. Mantinha-se a instituição do júri, obrigatória em matéria criminal para penas mais graves do que a prisão correccional ou quando os delitos fossem de carácter político. Não existe referência à magistratura do Ministério Público.

A eleição do Presidente da República ocorria no Congresso da República para um mandato de quatro anos, não podendo ser reeleito durante o quadriénio imediato, e podia ser destituído por maioria de dois terços; o Presidente da República nomeava e demitia livremente os ministros e os seus actos deviam ser referendados, pelo menos, pelo respectivo ministro competente; o Presidente da República não podia dissolver o Congresso da República, nem tinha o direito de veto. Os ministros eram politicamente responsáveis perante o Congresso da República, sendo autorizada a sua comparência e a sua intervenção em defesa dos seus actos.

Os novos símbolos nacionais - a bandeira verde e vermelho, com escudo das armas nacionais, 5 quinas, 7 castelos e esfera armilar manuelina, e o hino $A$ Portuguesa - foram confirmados por decreto de 19 de junho de 1911 da

15 Comenta o constitucionalista Jorge Miranda: "Não foi apenas por influência da Constituição brasileira [de 1891]; foi ainda, sobretudo, por razões internas (antes de mais a reacção contra os decretos ditatoriais de antes de 1910) que a Constituição reconheceu aos tribunais uma competência de apreciação da constitucionalidade das leis, segundo o modelo americano. E a Lei Fundamental de 1911 foi mesmo a primeira Constituição europeia a prever expressamente tal competência, o que pode considerar-se um dos mais positivos elementos da obra constituinte da $1^{a}$ República", Manual de Direito Constitucional, op. cit., vol. I, pp. 295-296. 
Assembleia Nacional Constituinte ${ }^{16}$, mas não obtiveram inscrição jurídica na Constituição de 1911. Apesar da extinção das ordens honoríficas, os feitos civicos e os actos militares podiam ser distinguidos com diplomas especiais, proibindo-se a aceitação de condecorações estrangeiras (artigo $3 .^{\circ}$ ). Dentro do ambiente da Primeira Guerra Mundial, para reforçar a dimensão simbólica das virtudes civicas, culturais e militares republicanas, serão restabelecidas oficialmente as ordens militares honoríficas, sendo o Presidente da República o grão-mestre de todas as Ordens: Ordem de Avis (25 de setembro de 1917), Ordem da Torre e Espada (26 de setembro de 1917), Ordem de Cristo e Ordem de S. Tiago de Espada (6 de dezembro de 1918) ${ }^{17}$.

\section{PROJECTO DA COMISSÃO DA CONSTITUIÇÃO}

O Projecto da Comissão da Constituição (Projecto de Lei $n^{\circ} 3$, de 3 de julho de 1911) ${ }^{18}$ foi apresentado pelo deputado Eduardo Abreu ${ }^{19}$, por indicação do relator desse projecto, Sebastião de Magalhães Lima (1850-1928), advogado, jornalista, grão-mestre do Grande Oriente Lusitano Unido/Supremo Conselho da Maçonaria Portuguesa e deputado eleito pelo círculo $n^{\circ} 34 /$ Lisboa Oriental, na sessão $n^{\circ} 12$, de 3 de julho de 1911, para discussão pública e pretendeu integrar ideias constantes dos vários Projectos Constitucionais divulgados:

"Cumprindo o honroso mandato de vós recebido, estudámos os projectos de Constituição que nos foram enviados por intermédio da Presidência desta Assembleia, e ainda aqueles de que, por outra forma, tivemos conhecimento. Agradecendo aos

16 Diário do Governo, no 141, 20 de junho de 1911, p. 2601: "O Decreto de 19 de junho de 1911, da Assembleia Nacional Constituinte, veio dispor: $1^{\circ}$ - A Bandeira Nacional é bipartida verticalmente em duas cores fundamentais, verde escuro e escarlate, ficando o verde do lado da tralha. Ao centro, e sobreposto à união das duas cores, terá o escudo das Armas Nacionais, orlado de branco e assentando sobre a esfera armilar manuelina, em amarelo e avivada de negro. As dimensões e mais pormenores de desenho, especialização e decoração da bandeira são os do parecer da comissão nomeada por decreto de 15 de outubro de 1910, que serão imediatamente publicados no Diário do Governo. 2 ${ }^{\circ}$ - O Hino Nacional é A Portuguesa". Quanto à bandeira nacional, seria publicado dois dias depois o parecer técnico sobre as suas medidas e proporções, como das bandeiras regimentais e do jack para os navios, cf. Diário do Governo, $\mathrm{n}^{\circ} 150,30$ de junho de 1911, pp. 2756-2757.

17 Ernesto Castro Leal, "República Portuguesa, secularização e novos símbolos (1910-1926)", Revista da Faculdade de Letras - História, III série, vol. 11, 2010, pp. 121-134; Nuno Severiano Teixeira, Heróis do Mar. História dos símbolos nacionais, A Esfera dos Livros, Lisboa, 2015.

18 Actas da Assembleia Nacional Constituinte de 1911 (De 15 de junho a 25 de agosto), Assembleia da República, Lisboa, 1989 [1911], pp. 28-35. A Comissão da Constituição era formada pelos deputados Francisco Correia de Lemos, procurador da República (presidente), José Barbosa, funcionário público (secretário), José de Castro, advogado, proprietário e grão-mestre adjunto do Grande Oriente Lusitano Unido, João de Meneses, advogado e jornalista, e Sebastião de Magalhães Lima, jornalista e grão-mestre do Grande Oriente Lusitano Unido (relator). Os outros projectos constitucionais, apesar da sua edição autónoma (com excepção do de Tomás Cabreira), também constam nesse livro.

19 O deputado Eduardo Augusto da Rocha Abreu (1855-1912), médico, eleito pelo círculo $\mathrm{n}^{\circ}$ 48/Angra do Heroísmo-Açores, justificou desta forma a leitura do Projecto da Comissão da Constituição: "O Sr. Magalhães Lima redigiu e estava encarregado de apresentar o projecto de lei que aqui tenho. Há pouco declarou-me, que tinha de ler o projecto de Constituição política da República, e por isso me pedia, para o substituir no encargo da apresentação deste projecto. Aceitei tão honrosa missão com que me honrou o meu amigo Dr. Magalhães Lima, de alma, vida e coração...", Actas da Assembleia Nacional Constituinte de 1911, op. cit., p. 35. 
autores desses projectos o haverem-nos proporcionado elementos para o nosso trabalho, consignamos o seu patriótico empenho em assegurar à Nação portuguesa uma lei orgânica.

O nosso esforço consistiu em encontrar uma fórmula conciliadora, sem ofender os princípios democráticos nem lesar os interesses nacionais. Se o conseguimos ou não di-lo-á a Assembleia Nacional Constituinte, que discutirá como entender e se pronunciará livremente sobre o projecto de lei que ao exame submetemos, com a solene afirmação de havermos procedido desinteressadamente e movidos pelo desejo de bem servir a nossa Pátria e a República”20.

Este projecto consagrava um modelo constitucional na forma de Estado unitário, a forma de governo a "República Democrática" (artigo $1^{\circ}$ ), em regime administrativo descentralizador (províncias e municípios), e um sistema de governo de "forma híbrida" - nem parlamentar, nem presidencial -, na opinião do constitucionalista Jorge Miranda ${ }^{21}$, com bicameralismo do Congresso da República (Conselho Nacional e Conselho dos Municípios) (artigo 6 $6^{\circ}$ ), sendo paritária a iniciativa legislativa das duas câmaras.

Constituía-se a segunda câmara a partir de um organicismo administrativo municipal, o que exigiu o enunciado das provincias, que agregavam municipios, segundo a tradição política do Manifesto e Programa de 1891 do Partido Republicano Português, elaborado por Teófilo Braga. Dentro do território português continental europeu estabelecia-se oito províncias: Minho, Douro, Trás-os-Montes, Beira Alta, Beira Baixa, Estremadura, Alentejo e Algarve (artigo $3^{\circ}$ ). Seguia-se o mapa provincial do liberal monárquico José Xavier Mouzinho da Silveira (1780-1849), que constava da proposta de reforma administrativa de 1832/1833, também adoptado pelo republicano federal Augusto Manuel Alves da Veiga (1850-1924)22. Estabelece-se neste projecto a "independência e harmonia" dos três poderes do Estado (artigo $5^{\circ}$ ).

Quanto ao poder legislativo (Congresso da República), o Conselho Nacional compunha-se de deputados do povo, maiores de 25 anos, eleitos por três anos através de sufrágio directo (não se refere que seja universal), e o Conselho dos Municípios por deputados dos municipios, maiores de 35 anos, eleitos por seis anos pelos vereadores municipais em exercício, sendo cinco por cada província do continente, dois por cada arquipélago e um por cada província do ultramar, pela forma como a lei eleitoral determinar. Nota-se uma semelhança com a Assembleia Federal Suiça (Conselho Nacional e Conselho dos Estados). Pode deduzir-se que a natureza do sufrágio seria masculino, e progressivamente feminino, dado que "A República assegurará a educação progressiva da mulher de maneira a permitirlhe o exercício da capacidade política e civil" (artigo $54^{\circ}, \mathrm{n}^{\circ} 12$ ).

20 Actas da Assembleia Nacional Constituinte de 1911, op. cit., p. 28.

21 Jorge Miranda, "A Assembleia Constituinte e a Constituição de 1911 - Um relance geral”, op. cit., p. 29.

22 Alves da Veiga, “Administration”, en M. M. Brito Aranha et al., Le Portugal - Géographique, Ethnologique, Administratif, Économique, Littéraire, Artistique, Historique, Politique, Colonial, etc., Larousse, Paris, s.d. [c. 1900], p. 78; Ernesto Castro Leal, "Augusto Alves da Veiga e a República", en Ernesto Castro Leal (edit.), República e Liberdade, Centro de História da Universidade de Lisboa, Lisboa, 2011, pp. 21-36; Id., "O problema politico em Alves da Veiga: argumentos federalistas na Politica Nova”, Revista Reflexões, n 4, 2014, pp. 14-26. 
O poder executivo, delegação temporária do poder legislativo, era exercido pelo Presidente da República - não há referência a um Chefe do Governo - e pelos ministros de dez Ministérios: Interior; Justiça e Cultos; Finanças; Guerra; Marinha; Negócios Estrangeiros; Educação Nacional; Ultramar; Agricultura, Comércio e Indústria; Obras Públicas e Comunicações (artigo 28ㅇ․

No poder judicial previam-se como órgãos o Supremo Tribunal de Justiça e os Tribunais distribuídos pelo País; criava-se um Alto Tribunal da República para julgamento do Presidente da República, ministros, deputados e seus co-réus, por crimes de responsabilidade; os Tribunais têm a competência da fiscalização da constitucionalidade das leis.

A eleição do Presidente da República tinha lugar no Congresso da República para um mandato de quatro anos, não podendo ser reeleito durante o quadriénio imediato e podia ser destituido por maioria de dois terços; nomeava e demitia livremente os ministros, os quais não eram politicamente responsáveis perante o Congresso da República e não podiam aí comparecer e intervir; os actos do Presidente da República deviam ser referendados, pelo menos, por um ministro, e estava impedido de dissolver o Congresso da República, nem tinha direito de veto.

\section{INDICAÇÕES PARA A CONSTITUIÇÃo POLÍTICA DA REPÚBliCA PORTUGUESA}

As Indicações para a Constituição Politica da República Portuguesa de Joaquim Teófilo Fernando Braga (1843-1924), Chefe do Governo Provisório e deputado eleito pelo círculo $n^{\circ}$ 35/Lisboa Ocidental, foram apresentadas em 19 de junho de 1911 "como oferta" à consideração da Assembleia Nacional Constituinte 23 .

O modelo constitucional apresentava a forma de Estado unitário descentralizado, a forma de governo a "República democrática parlamentar" (artigo 48 ) e o sistema de governo parlamentar (de assembleia), com unicameralismo do Parlamento (Câmara dos Deputados), eleito por três anos.

Logo no início do seu projecto, Teófilo Braga afirmava o princípio do nacionalismo histórico republicano, que se construiu a partir dos discursos celebrativos republicanos sobre III Centenário da Morte de Luís de Camões (junho de 1880), com a sua participação activa, dentro de um imaginário político da criação de uma religião cívica, através de "sinteses afectivas" ao redor das comemorações de centenários de figuras exemplares ou de acontecimentos representativos 24 :

\footnotetext{
"Portugal, que entre os Estados hispânicos foi o primeiro que, constituindo-se em Nação, manteve a sua unidade e independência através dos equilíbrios políticos ibéricos e europeus, unidade não enfraquecida pela extensão dos seus domínios geográficos e coloniais, procura manter sobre a persistência da sua situação,
}

23 Actas da Assembleia Nacional Constituinte de 1911, op. cit., pp. 543-551; Teófilo Braga, Indicações para a Constituição Política da República Portuguesa apresentadas à consideração da Assembleia Nacional Constituinte de 19 de junho de 1911, s.n., s.1.,1911.

${ }_{24}$ Amadeu Carvalho Homem, A Ideia Republicana em Portugal. O contributo de Teófilo Braga, Minerva, Coimbra, 1989, pp. 133-206; Ernesto Castro Leal, "A ética positivista de Teófilo Braga: virtude moral e dever cívico dos centenários”, Estudos Filosóficos, n 11, 2013, pp. 59-74. 
revigorando-se pela forma de República, a autonomia, afirmando a plena neutralidade internacional no concurso mundial da civilização moderna" (artigo $1^{\circ}$ )"; "Da autonomia do território de Portugal derivam as formas da sua administração em associações locais (estatuto territorial) e as garantias individuais pelo indigenato (estatuto pessoal), unificadas na Constituição Política, ou Código de Direito Político Português, que as torna efectivas" (artigo $3^{\circ}$ )"25.

O território português continental europeu era dividido em sete províncias: Trás-os-Montes, Minho, Beira Alta, Beira Baixa, Estremadura, Alentejo e Algarve (artigo $2^{\circ}$ ), conforme as "tradições étnicas regionais", a geomorfologia, a densidade populacional e a produção económica; as províncias subdividiam-se em distritos, concelhos ou municipios, e freguesias ou paróquias (artigo $4^{\circ}$ ); enquanto se não estabelecesse a autonomia das províncias com o seu governo administrativo devia existir em cada distrito um governador representante do poder central (artigo $5^{\circ}$ ).

Afirma-se a "harmonia da mútua independência dos poderes do Estado, unificando-os em uma síntese moral ou ordem consciente" sendo "representante da unidade dessa soberania indivisivel o Presidente da República parlamentar" (artigo $51^{\circ}$ ). O projecto estabelecia quem era "cidadão activo" com direito de sufrágio: os portugueses de maioridade de 21 anos, solteiros; os casados chefes de família, os que sabem ler, os que, conforme o censo, possuam propriedade imóvel, rendimentos de capital mutuado, indústria, comércio ou função subsidiada (artigo $16^{\circ}$ ). A redacção estava ambígua mas pode concluir-se que o sufrágio era capacitário dado que, na segunda parte, se refere os chefes de família, a literacia, a propriedade e o rendimento.

Ao poder legislativo (Parlamento/Câmara de Deputados) incumbia uma "função legislativa-parlamentar" e o deputado com mandato livre representaria toda a nação, "sendo improcedentes quaisquer restrições à localidade por onde for eleito" (artigo $70^{\circ}$ ), revendo Teófilo Braga a sistemática propaganda politica sobre o mandato imperativo (e sobre o sufrágio universal) que fizera anteriormente desde o seu Manifesto e Programa de Candidatura a Deputado, datado de 10 de junho de 1878 e apresentado às eleições legislativas de 13 de outubro desse ano pelo círculo $\mathrm{n}^{\circ} 94$ (Alfama/Lisboa) ${ }^{26}$. Teófilo Braga previa a possibilidade de uma Segunda Câmara (de Senadores ou Pares) para a apreciação das leis, que pela sua importância deviam ser aí discutidas (artigo $74^{\circ}$ ).

O poder executivo (Governo ou Ministério) detinha a "função executivaadministrativa": Presidente da República, com a "função coordenadora de todos os Poderes do Estado" (alusão a um Vice-Presidente da República, que era o Presidente do Conselho de Ministros no impedimento do Presidente da República); Presidente do Conselho de Ministros e ministros de quatro Ministérios que se subdividiam em pastas: Ordem e Educação Pública; Riqueza e Economia Pública; Defesa e Segurança Pública; Justiça e das Relações Internacionais (artigo $76^{\circ}$ ). Em relação ao que constava no Manifesto e Programa de 1891 do

25 Actas da Assembleia Nacional Constituinte de 1911, op. cit., p. 545.

26 Teófilo Braga, História das Ideias Republicanas em Portugal, Vega, Lisboa, 1983 [1880], pp. 109-111; José Esteves Pereira, "Teófilo Braga e Sílvio Romero: duas perspectivas sociológicas”, en José Esteves Pereira, Percursos de História das Ideias, Imprensa Nacional-Casa da Moeda, Lisboa, 2004, pp. 355-371; Ernesto Castro Leal, "Moral, politica e nação no pensamento de Teófilo Braga", Estudos Filosóficos, nº 9, 2012, p. 1-13. 
Partido Republicano Português, acrescentou o último Ministério. O Governo era uma delegação temporária do exercício das funções legislativas, das funções administrativas-executivas e das funções administrativas-contenciosas.

Para o poder judicial (Justiça ou Magistratura) estava reservada a "função executiva-contenciosa ou judicial": o Ministério Público (Procurador-Geral da República, com os seus juízes ajudantes; delegados do Procurador Geral juntos dos juizes colectivos nas Relações e dos juízes singulares nas Comarcas e Varas), que valorizava muito, e a Ordem Judicial (Tribunais); não surge a alusão ao Supremo Tribunal de Justiça.

O Presidente da República era eleito pela Câmara dos Deputados por cinco anos (impedida a reeleição no imediato quinquénio) e tinha a função de representar a Nação em todas as relações internacionais; os seus actos deviam ser referendados por um ministro, incluindo as mensagens enviadas ao Parlamento; escolhia, nomeava e demitia os ministros, que seriam responsáveis perante a Câmara dos Deputados; não podia dissolver a Câmara dos Deputados, nem tinha direito de veto.

Mantendo uma ideia propagandeada desde a década de 1870, Teófilo Braga concebia o desempenho das relações da República Portuguesa com os outros Estados através de um corpo consular, encarregados de negócios e enviados extraordinários, apenas mantendo as embaixadas do Brasil e da Inglaterra "pela importância dos mútuos interesses económicos especialíssimos” (artigo 83).

\section{BASES PARA A CONSTITUIÇÃO POLÍTICA DA REPÚBLICA PORTUGUESA}

As Bases para a Constituição Politica da República Portuguesa de António Maria de Azevedo Machado Santos (1875-1921), oficial da Administração Naval, chefe militar da Revolução de 5 de outubro de 1910 e deputado eleito pelo círculo $n^{\circ} 35 /$ Lisboa Ocidental, foram apresentadas na sessão $n^{\circ} 6$ da Assembleia Nacional Constituinte, em 23 de junho de $1911^{27}$.

O modelo constitucional estabelecia a forma de Estado unitário descentralizado, a forma de governo "republicano" (artigo $1^{\circ}$ ) e o sistema de governo presidencial (imperfeito), dado que o Presidente era eleito na Assembleia Nacional, com bicameralismo da Assembleia Nacional (1 ${ }^{\mathrm{a}}$ Secção e $2^{\mathrm{a}}$ Secção), eleita por quatro anos, sendo paritária a iniciativa legislativa das duas secções, constituídas a partir de organicismos administrativos, sociais e culturais.

O território português continental europeu era dividido em sete provincias: Trás-os-Montes, Minho, Douro, Beiras, Estremadura, Alentejo e Algarve; as províncias subdividiam-se em municípios, em regime de descentralização e autonomia, podendo federarem-se após aprovação da Assembleia Nacional (artigo $2^{\circ}$ ). Afirma-se que os "poderes políticos, embora coordenados, são completamente independentes e nenhum pode invadir as atribuições dos outros" (artigo 9).

O poder legislativo (Assembleia Nacional) dividia-se na $1^{\text {a }}$ Secção, composta por representantes de todos os municipios do continente, das ilhas adjacentes e das provincias coloniais, e na $2^{\mathrm{a}}$ Secção, composta por representantes das

27 Actas da Assembleia Nacional Constituinte de 1911, op. cit., p. 561-567. Uma primeira versão mais reduzida tinha sido publicada no jornal $O$ Intransigente, $\mathrm{n}^{\circ} 194,28$ de maio de 1911 , p. 1 . 
classes, institutos científicos e estabelecimentos do ensino superior; formavam a Mesa da Assembleia Nacional o Presidente da Assembleia Nacional (também Chefe de Estado), um Vice-Presidente e dois secretários, e cada uma das Secções tinham uma Mesa privativa; o sufrágio era capacitário masculino (saber ler e escrever) e feminino (curso secundário), maiores de 21 anos (artigo $4^{\circ}$ ).

Faziam parte do poder executivo (Conselho do Governo) o Presidente da Assembleia Nacional e os secretários de estado da sua livre escolha em oito Secretarias de Estado: Interior e Justiça; Exterior; Fazenda; Comércio e Indústria; Obras Públicas e Comunicações; Ciências e Artes; Colónias; Defesa Nacional (artigo $22^{\circ}$ ); os membros do Conselho do Governo podiam apenas assistir às sessões da Assembleia Nacional.

O poder judicial exercia-se através do Supremo Tribunal de Justiça, de Tribunais de segunda instância (compostos de juizes togados) e de Tribunais de primeira instância (compostos de juizes togados e de jurados); a magistratura judicial (independente, forma um quadro composto unicamente por juizes) e a magistratura do Ministério Público (quadro de nomeação pelo poder executivo).

António Machado Santos rememoraria em 1916 estas Bases, considerando (erradamente) que exprimiam as ideias politico-constitucionais presentes no Manifesto e Programa de 1891 do Partido Republicano Português, como se pode verificar ao comparar as duas formas de Estado, os dois sistemas de governo e a natureza do sufrágio: "O que pensámos, ao tempo [na Assembleia Nacional Constituinte], sobre essa base jurídica, caso se quisesse cumprir integralmente o antigo programa do partido republicano [de 1891] e desviar politicos e proletários da acção directa, ficou expresso no projecto de constituição que aprestámos e circulou impresso..."28.

\section{CONSTITUIÇÃO OU CÓDIGO FUNDAMENTAL DA REPÚBLICA PORTUGUESA}

A Constituição ou Código Fundamental da República Portuguesa de Fernão Amaral Boto-Machado (1865-1924), solicitador e deputado eleito pelo círculo $n^{\circ}$ 35/Lisboa Ocidental, foi apresentada na sessão $n^{\circ} 12$ da Assembleia Nacional Constituinte, em 3 de julho de 1911, e está datada de 30 de junho anterior ${ }^{29}$.

O modelo constitucional inscreveu a forma de Estado unitário descentralizado, a forma de governo "republicano e representativo, democrático e descentralizador" (artigo $2^{\circ}$ ) e o sistema de governo presidencial (imperfeito), dado que o Presidente era eleito no Congresso Nacional, com bicameralismo do Congresso Nacional ( $1^{\mathrm{a}}$ Instância e $2^{\mathrm{a}}$ Instância), eleito por quatro anos (possibilidade de reeleição), sendo não paritária a iniciativa legislativa, pois competia exclusivamente à $1^{\text {a }}$ Instância, mas tinha de ser aprovada pela $2^{a}$ Instância ou, em caso de dúvida, sujeita a plebiscito ou referendum dos vereadores das câmaras municipais para se converter em Lei da República.

\footnotetext{
${ }^{28}$ Machado Santos, A Ordem Pública e o 14 de Maio, Liberty, Lisboa, 1916, pp. 14-15.

29 Actas da Assembleia Nacional Constituinte de 1911, op. cit, pp. 595-606; Fernão BotoMachado, Constituição ou Código Fundamental da República Portuguesa. Projecto apresentado à Assembleia Nacional Constituinte, Bayard, Lisboa, 1911.
} 
Fernão Boto-Machado fez preceder o seu projecto de uma longa introdução, quando foi publicado em opúsculo, reflectindo sobre a filosofia política do projecto e as principais inovações que ele continha. Mostrava simpatia pela forma de Estado federal mas considerava-a inviável em Portugal - o limite, para si, era a autonomia distrital:

\begin{abstract}
"Quase todas as repúblicas são federais. A Áustria e a Alemanha são confederações. Ao regime federal deve a América Inglesa a sua vertiginosa prosperidade. Com pesar deixo de propor que Portugal siga esta corrente. Autonomia e federalismo são coisas bem diversas; mas considero aquela um grande passo dado para a realização deste. Se as aspirações federativas dos girondinos não tivessem sido sacrificadas ao unitarismo da Montanha, deixaria a França de ter sido açoitada pelo vendaval das revoluções. Nem Napoleão I, nem Napoleão III teriam deixado sulcos tenebrosos na História"30.
\end{abstract}

Neste projecto não há, por conseguinte, a divisão provincial do território português continental europeu, visto que, a nivel administrativo, apenas existia a comuna (paróquia/freguesia), o municipio e o distrito, que eram soberanos e autónomos nas respectivas circunscrições (artigo $9^{\circ}$ ). Afirma-se que os poderes de Estado são "absolutamente independentes mas impõe-se-lhes o dever supremo de viverem harmonicamente e sem conflitos" (artigo $37^{\circ}$ ).

Como principio da moral laica republicana, Fernão Boto-Machado adoptou da moralidade do filósofo Immanuel Kant o "imperativo categórico" - "Age apenas segundo uma máxima tal que possas ao mesmo tempo querer que ela se torne lei universal" - e o "imperativo prático" - "Age de tal maneira que uses a humanidade, tanto na tua pessoa como na pessoa de qualquer outro, sempre e simultaneamente como fim e nunca // simplesmente como meio"31. Sistematizou-os, da seguinte maneira, no seu projecto constitucional: "Todo o bom cidadão deve proceder na sociedade considerando o seu semelhante como fim, e não como meio, e de maneira tal que a máxima de qualquer acção possa erigir-se em princípio de legislação moral e universal" (artigo $\left.12^{\circ}\right)^{32}$.

30 Fernão Boto-Machado, Constituição ou Código Fundamental da República Portuguesa, op. cit., p. XIV.

31 Immanuel Kant, Fundamentação da Metafísica dos Costumes. Tradução de Paulo Quintela, Edições 70, Lisboa, 2014, pp. 62 e 73. Segundo a análise crítica do filósofo Pedro Galvão, "Na Fundamentação, Kant exprimiu o imperativo categórico através de diversas fórmulas que, pelo menos superficialmente, são bastante distintas... A primeira delas é a fórmula da lei universal [imperativo categórico]... Uma segunda expressão do imperativo categórico é a fórmula da humanidade [imperativo prático]... Outra expressão do imperativo categórico, a fórmula de autonomia, surge-nos de um modo muito elíptico: 'a ideia da vontade de todo o ser racional concebida como vontade legisladora universal... Por fim, importa destacar uma variante importante da fórmula da autonomia, que se tornou conhecida por 'fórmula do reino dos fins': Age segundo máximas de um membro universalmente legislador em ordem a um reino dos fins somente possivel... Kant (BA 80) alega que todas as fórmulas indicadas captam a mesma lei prática. Contudo, é evidente que as fórmulas não são sinónimas, não significam precisamente o mesmo...", cf. "Introdução", en Immanuel Kant, Fundamentação da Metafísica dos Costumes, op. cit., pp. XIVXVII.

32 Justificou assim esse artigo constitucional: "Principios de moral. Como o Estado republicano não tem, nem deve ter religião oficial, consignámos no $\operatorname{art}^{\mathrm{o}} 12 \mathrm{o}$ imperativo categórico de Kant, que vale bem mais que o não faças a outrem o que não queres que te façam, da religião cristã”, Fernão Boto-Machado, Constituição ou Código Fundamental da República Portuguesa, op. cit., p. XV. 
O poder legislativo (Congresso Nacional) organizava-se em duas câmaras: 1 a $^{a}$ Instância, composta de eleitos pelas províncias ultramarinas e de cento e cinquenta e cinco eleitos no continente e ilhas adjacentes, através de sufrágio universal - "A Constituição republicana garante a todo o cidadão...; $3^{\circ}$ - Ser militar, eleitor e elegível, apenas atingir a maioridade" (artigo 14\%) -, directo e proporcional; 2. ${ }^{a}$ Instância, composta por um eleito por cada província ultramarina e de dois por cada distrito, eleitos pelas câmaras distritais, com mandato de quatro anos e reelegiveis; instituía-se um Supremo Tribunal de Revisão Legislativa. O Congresso Nacional elegia o Presidente do Congresso Nacional, o $1^{\circ}$ Vice-Presidente (Presidente da $2^{a}$ Instância legislativa), o $2^{\circ}$ VicePresidente (Presidente da $1^{\text {a }}$ Instância legislativa) e o Presidente do Poder Executivo.

Uma modernidade constitucional, que não estará presente em mais nenhum Projecto Constitucional nem na Constituição de 1911, foi a consagração dos partidos políticos. Determinava-se a criação no Ministério do Interior de uma repartição denominada Registo dos Partidos Políticos (artigo $113^{\circ}$ ) e definia-se com precisão as condições para o seu registo oficial: "1 ${ }^{\circ}$ - Que adopte um nome característico; $2^{\circ}$ - Que tenha programa definido; $3^{\circ}$ - Que tenha um ou mais centros constituídos, com regulamento, e, pelo menos, 300 sócios; $4^{\circ}$ - Que tenha um órgão, pelo menos semanal, na imprensa; $5^{\circ}$ - Que peça a sua inscrição no Ministério, em requerimento subscrito por mais de 100 sócios" (artigo $114^{\circ}$ ). Reforçando essa consciência partidária, o articulado determinava que os “eleitores não votarão em pessoas, mas em partidos" (artigo 117º).

Na Lei de Revisão Constitucional de 1919 (Lei $\mathrm{n}^{\circ}$ 891, de 22 de setembro de 1919), com a atribuição da competência de dissolução do Congresso da República conferida ao Presidente da República, criou-se, para sua consulta, o Conselho Parlamentar, presidido pelo Presidente do Congresso da República; foi a primeira inscrição constitucional oficial portuguesa dos partidos e grupos políticos e dos seus grupos parlamentares:

\footnotetext{
"Compete ao Presidente da República:

... $10^{\circ}$ - Dissolver as Câmaras Legislativas quando assim o exigirem os superiores interesses da Pátria e da República, mediante prévia consulta do Conselho Parlamentar. $\S 1^{\circ}$ - Este Conselho, que não poderá ter mais de dezoito membros, será eleito pelo Congresso na primeira sessão depois da promulgação desta lei, de forma a nele serem representadas todas as correntes da opinião na seguinte proporção: 4 membros do Congresso elegem 1; 5 a 15, 2; 16 a 45, 3; 46 a 90, 4; 90 por diante, $5 \ldots$ "33.
}

O poder executivo era composto pelo Presidente do Poder Executivo (Presidente da República), eleito por cinco anos (não reelegivel), e pelo Governo com ministros nomeados e demitidos livremente e politicamente responsáveis perante ele, que chefiavam oito Ministérios, com esta precedência: Instrução Pública e Belas Artes; Interior (compreendendo os negócios eclesiásticos e uma secção de registo dos partidos políticos); Trabalho e Solidariedade Social; Defesa Terrestre; Defesa Marítima e Províncias Ultramarinas; Finanças; Estrangeiros (negócios diplomáticos e consulares); Fomento (agricultura, comércio, indústria,

33 Diário do Governo, I série, n 192, 22 de setembro de 1919, p. 2011. 
correios e telégrafos e obras públicas); não consta o Ministério da Justiça (artigo $\left.81^{\circ}\right)$.

O projecto de Fernão Boto-Machado consagrava o Conselho de Estado (dois membros escolhidos pela $1^{\mathrm{a}}$ Instância Legislativa, dois pelo Presidente da República, um pelo Presidente do Supremo Tribunal de Justiça, dois pelo Presidente dos Vigilantes da Constituição e um pelo Procurador-Geral da República), órgão que não existiria durante a I República, mas que tivera inscrição constitucional durante a Monarquia Liberal na Constituição de 1822 e na Carta Constitucional de 1826 (com terceira vigência entre 1842-1910), apenas não estando previsto na Constituição de 1838, voltando a funcionar no Estado Novo e na Democracia.

O poder judicial era titulado por juízes (os da $1^{\text {a }}$ e $2^{a}$ Instância e do Supremo Tribunal de Justiça são eleitos), magistrados do Ministério Público e jurados; Supremo Tribunal de Justiça (1 ${ }^{\text {a }}$ Secção/civel e comercial, $2^{a}$ Secção/criminal, $3^{a}$ Secção/garantias individuais e direitos constitucionais - Câmara dos Censores "vigilantes especiais da Constituição"). Outra novidade era esta Câmara dos Censores, constituída por sete juízes eleitos: um pela $1^{\text {a }}$ Instância legislativa; um pela $2^{a}$ Instância legislativa; um pelos oito ministros de Estado; um na $1^{\text {a }}$ Secção e outro na $2^{\text {a }}$ Secção do Supremo Tribunal de Justiça; um pela Academia das Ciências de Lisboa e pelo corpo docente do Curso Superior de Letras, da Escola Politécnica e da Escola Médica; um pelas assembleias gerais da Sociedade de Geografia, das Associações Comercial, Industrial, Agrícola e de Lojistas de Lisboa; um pelo claustro pleno da Universidades (artigo $20^{\circ}$ ).

\section{BASES PARA A CONSTITUIÇÃO DA REPÚBLICA PORTUGUESA}

As Bases para a Constituição da República Portuguesa, datadas de 1 de julho de 1911, foram apresentadas por Manuel Goulart de Medeiros (1861-1947), major de Artilharia e deputado eleito pelo círculo n ${ }^{\circ}$ 49/Horta-Açores ${ }^{34}$.

O modelo constitucional estabeleceu a forma de Estado federal descentralizado, a forma de governo a "república federal democrática" (base $1^{\text {a) }}$ e o sistema de governo convencional (na opinião do constitucionalista Jorge Miranda ${ }^{35}$ ), com bicameralismo do Congresso Nacional (Câmara Nacional e Senado), eleito por três anos, sendo paritária a iniciativa legislativa. O território português continental europeu dividia-se em seis províncias: Minho, Trás-osMontes, Beira, Estremadura, Alentejo e Algarve (base $1^{\text {a)}}$ ); estas em distritos, municípios e freguesias ou paróquias. A soberania era delegada em apenas dois poderes de Estado (legislativo e judicial), "inteiramente independentes" (base $8^{\mathrm{a}}$ ), sendo o primeiro de eleição directa e o segundo de eleição indirecta.

O poder legislativo nacional (Congresso Nacional) era constituído pela Câmara Nacional, câmara dos deputados da nação eleita em lista de um só nome,

34 Actas da Assembleia Nacional Constituinte de 1911, op. cit., pp. 607-614; Manuel Goulart de Medeiros, Bases para a Constituição da República Portuguesa, Cooperativa Militar, Lisboa, 1911; João Bosco Mota Amaral, "Um Açoreano na fundação da República. Manuel Goulart de Medeiros e o seu projecto de Constituição", Boletim do Núcleo Cultural da Horta, no 19, 2010, pp. $135-145$. http://www.nch.pt/biblioteca-virtual/bol-nch19/BoletimNCH-19-135.pdf

35 Jorge Miranda, "A Assembleia Constituinte e a Constituição de 1911 - Um relance geral”, op. cit., p. 31. 
e pelo Senado, câmara dos deputados dos distritos eleita por três representantes de cada distrito, para uma legislatura de três anos, sendo paritária a iniciativa de uma lei, que devia ser aprovada pelas duas câmaras. Os poderes legislativos inferiores organizavam-se em Juntas Provinciais (dois representantes de cada distrito), Juntas Distritais (dois representantes de cada municipio), Juntas Municipais (dois representantes de cada freguesia) e Juntas Paroquiais (por sete membros eleitos na freguesia). As províncias formadas de um só distrito não terão Junta Provincial, pertencendo as atribuições desta à Junta Distrital. Projecta-se no Senado e nas Juntas um organicismo administrativo.

Apesar de se afirmar que o "sufrágio é universal" (base $8^{a}$ ), o certo é que apenas se concedia o voto masculino de maiores de 20 anos (base $4^{\mathrm{a}}$ ) e o voto feminino de maiores de 20 anos desde que fossem "chefes de familia ou fogo, que sustentarem essa família com os seus rendimentos $\mathrm{e}$ as que viverem independentes e dos seus rendimentos legítimos. As maiores de 20 anos, que vivem com os seus pais, maridos ou outras pessoas, que as sustentarem, não terão os direitos de cidadãos sem autorização dos respectivos chefes de família" (base $5^{\mathrm{a}}$ ). Por conseguinte, o sufrágio era capacitário, quase universal.

A cada "corpo legislativo" (Congresso Nacional e Juntas) correspondia um "corpo executivo" (Ministério e Comissões Executivas), politicamente responsáveis perante o "corpo legislativo". O Congresso Nacional elegia o Presidente do Congresso Nacional (era o Presidente da República), o Procurador da República e a Mesa do Congresso Nacional. Havia um Presidente de Ministério eleito pelo Congresso Nacional, que escolhia seis ministros, não existindo a indicação do nome das pastas ministeriais; as Comissões Executivas das Juntas teriam três elementos, sendo o Presidente eleito pela Junta, o qual escolhia os outros dois.

Estabelecia-se como órgãos do poder judicial o Supremo Tribunal de Justiça, as Relações Provinciais, os Tribunais de Comarca, os Tribunais Municipais e os Juizes de Paz; junto de cada Tribunal funciona um agente do Ministério Público. A eleição dos juízes era feita por sufrágio indirecto: "O corpo eleitoral de juízes será formado por 9 cidadãos na freguesia, de 21 no município, de 51 na comarca, de... na província e de... na Nação. Este corpo eleitoral tem exercício bianual e poderá votar por escrito, sendo o voto reconhecido por notário e enviado para o lugar onde se realizar a eleição. Nenhum membro do corpo eleitoral poderá ser eleito juiz" (base $40^{\circ}$ ).

\section{PROJECTO CONSTITUCIONAL}

O Projecto Constitucional de Tomás António da Guarda Cabreira (1865-1918), oficial do Exército/Engenharia, professor da Escola Politécnica de Lisboa, economista político e deputado pelo círculo $n^{\circ} 46 /$ Faro, foi apresentado na sessão $\mathrm{n}^{\circ} 12$ da Assembleia Nacional Constituinte, em 24 de junho de $1911^{36}$. Muito curto, contemplava apenas cinco capitulos com 10 pequenos artigos, apresentando os princípios gerais, sendo o primeiro sobre a função da República: "A República Portuguesa, visando o progresso da Pátria e a sua integração na corrente das ideias modernas, assume a função de estimular, num sentido

${ }^{36}$ Actas da Assembleia Nacional Constituinte de 1911, op. cit., pp. 623-626. 
fecundo, a educação e a riqueza nacional e de congregar todos os cidadãos no mesmo espírito de concórdia e de liberdade" (artigo $1^{\circ}$ ).

O modelo constitucional instituía a forma de Estado unitário, a forma de governo a "República Portuguesa" (artigo $1^{\circ}$ ) e o sistema de governo convencional (directorial na opinião do constitucionalista Jorge Miranda ${ }^{37}$ ), com unicameralismo da Assembleia Nacional. A novidade estava no enunciado de cinco órgãos constitucionais da República: Assembleia Nacional; Ministério; Tribunais; Academias de Ciências e Universidades; Câmaras Sindicais da Produção Nacional (artigo $2^{\circ}$ ). Não havendo a nomeação formal dos poderes de Estado (legislativo, executivo e judicial), o certo é que eles estão corporizados nos três primeiros órgãos constitucionais.

O poder legislativo situava-se na Assembleia Nacional, constituída pelos procuradores da nação, que tinham, entre outras, as seguintes competências: elaborar e revogar as leis; eleger e destituir a Mesa da Assembleia Nacional e o Ministério; declarar a guerra e aceitar a paz; ratificar os tratados internacionais (artigo $3^{\circ}$ ). O Presidente da Assembleia Nacional era o Presidente da República. Não está descrita a capacidade eleitoral, por isso não se pode classificar com rigor a natureza do sufrágio, mas admite-se a possibilidade de ser um sufrágio universal: "Todos os cidadãos da República têm como direitos: a) Serem eleitores e elegiveis para todos os cargos políticos e administrativos..." (artigo $9^{\circ}$ ).

Faziam parte do poder executivo ministros de oito Ministérios: Instrução, Saúde e Administração Política e Civil; Justiça e Cultos; Fomento; Colónias; Obras Públicas; Finanças; Relações Externas; Defesa Nacional (artigo 4. ${ }^{\circ}$ ). Os ministros eram nomeados e demitidos pela Assembleia Nacional e, no intervalo parlamentar, essa competência passava para o Presidente da República. Apesar de não se referir a direcção dos trabalhos do Ministério pelo Presidente da República (dirigia os trabalhos da Assembleia Nacional), é provável que ele fosse também Presidente do Ministério. O Ministério executava as leis da Assembleia Nacional e elaborava os regulamentos.

Os Tribunais exerciam o poder judicial, interpretando as leis e ministrando a justiça social, e os juizes seriam inamoviveis (artigo $5^{\circ}$ ). O poder consultivo e de propaganda, de natureza orgânico-corporativa, exprimia-se através na redacção de pareceres, na proposta de medidas e na promoção de acções de propaganda (criar uma consciência nacional e uma solidariedade de todas as classes sociais), e pertencia aos outros dois órgãos constitucionais: as Academias de Ciências e as Universidades ("constituidas pelas mais altas capacidades mentais da República"); e as Câmaras Sindicais da Produção Nacional ("constituídas por delegados de todas as classes que representam as forças produtoras da Nação").

\section{PROJECTO DA CONSTITUIÇÃO PORTUGUESA}

O Projecto da Constituição Portuguesa, enviado pelo Grémio Montanha38 à Assembleia Nacional Constituinte, tem a data de 23 de junho de $1911^{39}$. Segundo

37 Jorge Miranda, “A Assembleia Constituinte e a Constituição de 1911 - Um relance geral”, op. cit., p. 31 .

38 O Grémio Montanha era o nome profano da maçónica Loja Montanha $\mathrm{n}^{\circ} 214$, que tinha como venerável Artur Luz de Almeida. Antes da Revolução republicana de 5 de outubro de 1910 , esta Loja teve uma forte ligação à Carbonária Portuguesa, pertencendo à direcção máxima [Alta 
o historiador António Ventura, o "projecto subscrito pela Loja Montanha, ainda que subscrito com a designação profana de 'grémio', possuía um significado especial dado o desempenho desta Oficina em prol da proclamação da República e a sua ligação à Carbonária Portuguesa"40. Mas esse projecto não vinculou todos os maçons da Loja Montanha, pois, como se viu, António Machado Santos, que pertencia aos seus quadros, apresentou um projecto autónomo de natureza diversa.

O modelo constitucional tipificava a forma de Estado federal, a forma de governo "republicano democrático e federativo" (artigo $2^{\circ}$ ), e o sistema de governo directorial, com unicameralismo da Assembleia Nacional, sendo o sufrágio universal e directo, pela forma que a lei determinar (artigo $6^{\circ}$ ). Não há uma descrição particularizada das províncias, apenas se refere, quanto ao território europeu, genericamente a Portugal continental e aos arquipélagos dos Açores e Madeira. Constitucionalizava, desta forma, o patriotismo civico republicano: "Fraternidade: é o sentimento que liga todos os portugueses como irmãos, filhos da mesma Pátria, e que os faz amarem-se mutuamente, defendendo-se e auxiliando-se e conjugando os seus esforços para conseguir o bem-estar de cada um e a prosperidade da Nação" (artigo 98²).

O poder legislativo denominava-se Assembleia Nacional, constituída por deputados, com mandato de quatro anos. Elegiam quer a Mesa da Assembleia Nacional, constituída pelo Presidente, dois vice-presidentes, dois secretários e dois vice-secretários, quer o Directório, que exercia o poder executivo e era composto de cinco secretários de estado (Defesa Nacional, Relações Diplomáticas, Relações com as Colónias, Administração Geral da Nação e Chanceler), não havendo alusão a um Presidente da República. Há uma separação entre o poder executivo e o poder legislativo, não existindo a possibilidade de dissolução mútua. Compunham o poder judicial os Juizes de Paz nas paróquias, os Tribunais de Comarca, os Tribunais de Relação e o Supremo Tribunal de Justiça; os juízes e os promotores eram magistraturas distintas.

Estava concebido um organicismo administrativo descentralista do território português através de federação de distritos autónomos, no continente e ilhas adjacentes, e de províncias autónomas, no ultramar (artigo $3^{\circ}$ ); cada distrito autónomo seria formado pela federação dos seus concelhos (artigo $4^{\circ}$ ); Câmaras Municipais e Comissão Executiva com um mínimo de cinco vereadores (concelhos); Assembleia ou Congresso Distrital e Junta Executiva com três membros (distritos).

Venda da Carbonária Portuguesa] dois elementos destacados da Loja: Artur Luz de Almeida (iniciado em 19 de julho de 1900 e fundador) e António Machado Santos (iniciado em 14 de julho de 1909); António José de Almeida, futuro membro do Governo Provisório da República, Presidente de Ministério e Presidente da República também pertenceu à Loja Montanha (iniciado em 3 de julho de 1907) e à Carbonária Portuguesa, cf. António Ventura, "Para a história da Loja Montanha. As três Lojas Montanha...", en Maria Inácia Rezola e Pedro Aires Oliveira (edits.), $O$ Eterno Retorno. Estudos em homenagem a António Reis, Campo da Comunicação, Lisboa, 2013, pp. 403-409, 419-420.

39 Actas da Assembleia Nacional Constituinte de 1911, op. cit., pp. 627-634; Projecto da Constituição Portuguesa enviado ao Parlamento pelo Grémio Montanha, Liberty, Lisboa 1911.

40 António Ventura, Uma História da Maçonaria em Portugal, 1727-1986, Círculo de Leitores, Lisboa, 2013, p. 470. 


\section{CONCLUSÕES}

A partir da análise dos sete Projectos Constitucionais escolhidos, apresentados por deputados - um deles pela Comissão da Constituição (composta por cinco deputados) e apresentado pelo Grémio Montanha - à Assembleia Nacional Constituinte de 1911, salienta-se, em sintese comparativa, os seguintes aspectos, radicados na diversidade de visões ideológico-políticas dentro do pensamento político republicano sobre os modelos de Estado:

a) Formas de Estado: só nos Projectos Constitucionais de Manuel Goulart de Medeiros e do Grémio Montanha se instituía o Estado federal, todos os outros reconheciam o Estado unitário de matriz descentralizadora.

b) Formas de Governo: República democrática (Comissão da Constituição), República democrática parlamentar (Teófilo Braga), Republicano (António Machado Santos), Republicano e representativo, democrático e descentralizador (Fernão Boto-Machado), República federal democrática (Manuel Goulart de Medeiros), República Portuguesa (Tomás Cabreira) e Republicana Democrática e Federativa (Grémio Montanha).

c) Sistemas de Governo: "híbrido" (Comissão da Constituição), parlamentar de assembleia (Teófilo Braga), presidencial imperfeito (António Machado Santos e Fernão Boto-Machado), convencional (Manuel Goulart de Medeiros e Tomás Cabreira) e directorial (Grémio Montanha); bicameralismo (Comissão da Constituição, António Machado Santos, Fernão Boto-Machado e Manuel Goulart de Medeiros) e unicameralismo (Teófilo Braga, Tomás Cabreira e Grémio Montanha). Nos projectos de indole presidencial, o Chefe de Estado era eleito no órgão do poder legislativo: Assembleia Nacional (António Machado Santos) e Congresso Nacional (Fernão Boto-Machado).

d) Províncias (continente português): oito (Comissão da Constituição), sete (Teófilo Braga e António Machado Santos) e seis (Manuel Goulart de Medeiros).

e) Ministérios ou Secretarias de Estado: dez Ministérios (Comissão da Constituição), oito Ministérios (Fernão Boto-Machado e Tomás Cabreira), seis Ministérios (Manuel Goulart de Medeiros), quatro Ministérios (Teófilo Braga); oito Secretarias de Estado (António Machado Santos) e cinco Secretarias de Estado (Grémio Montanha).

Quanto às inovações politicas presentes nos Projectos Constitucionais que não ficaram consagradas na Constituição de 1911, deve assinalar-se, por exemplo, a representação orgânico-corporativa no poder legislativo - Conselho dos Municípios (Comissão da Constituição) e Assembleia Nacional/1 ${ }^{\mathrm{a}}$ e $2^{\mathrm{a}}$ Secções (António Machado Santos); o Alto Tribunal da República (Comissão da Constituição), para o julgamento de titulares dos poderes executivo e legislativo, o Registo dos Partidos Políticos, o Supremo Tribunal de Revisão Legislativa, o Conselho de Estado e a Câmara dos Censores para o controlo da constitucionalidade das leis (Fernão Boto-Machado); as Academias de Ciências, as Universidades e as Câmaras Sindicais da Produção Nacional (Tomás Cabreira), órgãos constitucionais de natureza orgânico-corporativa, com poderes consultivos e de propaganda.

Em relação ao sufrágio universal - consagrado no Manifesto e Programa de 1891 do Partido Republicano Português -, o Projecto Constitucional do 
Grémio Montanha determinava o sufrágio universal, remetendo a sua precisão para uma lei eleitoral (artigo $6^{\circ}$ ); o Projecto Constitucional de Manuel Goulart de Medeiros, apesar de estabelecer o sufrágio universal de maiores de 20 anos (base $8^{a}$ ), restringia o voto feminino à situação de chefe de família, abrindo a hipótese, no caso de o não ser, à autorização de voto concedida pelos respectivos chefes de família (base $5^{\mathrm{a}}$ ) - era capacitário, quase universal; no Projecto Constitucional de Fernão Boto-Machado não se definia a capacidade eleitoral, mas pode deduzir-se o sufrágio universal dado que a Constituição garantia a todo o cidadão ser eleitor e elegivel, "apenas atingir a maioridade" (artigo $14^{\circ}$ ), e todo "o cidadão numa república democrática é rei por virtude da lei e do voto" (artigo $8^{\circ}$ ); também no Projecto Constitucional de Tomás Cabreira não se definia a capacidade eleitoral, mas pode admitir-se de igual modo a possibilidade do sufrágio universal quando afirma que "Todos os cidadãos da República têm como direitos: a) Serem eleitores e elegíveis para todos os cargos políticos e administrativos..." (artigo $9^{\circ}$ ).

Os Projectos Constitucionais da Comissão da Constituição, de Teófilo Braga e de António Machado Santos, com algumas particularidades, optaram, de facto, pelo sufrágio capacitário. A Constituição de 1911 não inscreveu a natureza do sufrágio, vindo a Lei Eleitoral (Lei $n^{\circ} 3$, de 3 de julho de 1913) a consagrar um sufrágio capacitário restrito: cidadãos masculinos, maiores de 21 anos, que soubessem ler e escrever, excluindo-se os militares do Exército e da Marinha no activo e os membros dos corpos da Polícia Cívica, assim como os condenados por crime de conspiração contra a República, os alienados, os interditos, os falidos, os condenados ou os indigentes. Essa Lei eleitoral foi aprovada por iniciativa do I Governo de Afonso Costa (9 de janeiro de 1913 a 9 de fevereiro de 1914), totalmente constituído por membros do Partido Republicano Português ("Partido Democrático", na linguagem política comum da época), que tinha no seu Programa, aprovado no Congresso de Braga (27 a 29 de abril de 1912) e mantido inalterado até ao final da I República, a consagração do sufrágio universal ${ }^{41}$.

Os simbolos nacionais (bandeira e hino), decretados em 19 de junho de 1911 pela Assembleia Nacional Constituinte, não obtiveram inscrição na Constituição de 1911. Dos Projectos Constitucionais analisados, só o Projecto do Grémio Montanha, de forma explícita, os consagra: "A Bandeira Nacional será verde e vermelha, com o escudo nacional assentado sobre a esfera armilar, conforme decretado, e o Hino Nacional será A Portuguesa" (artigo 106\%). A outra alusão, apenas respeitante à bandeira aprovada, sem a descrever concretamente, encontra-se no Projecto de Teófilo Braga: "A unidade territorial da Nação Portuguesa é representada pela sua bandeira ou pavilhão, caracterizado pelas cores e emblemas, que sintetizam a sua ocupação histórica e defesa constante" (artigo $13^{\circ}$ ). Apesar de não terem sido constitucionalizados na Constituição de 1911 (I República) e na Constituição de 1933 (Estado Novo), esses símbolos nacionais mantiveram-se sempre em vigor e só obteriam recepção na Constituição 1976 (Democracia): “1. A Bandeira Nacional é a adoptada pela

41 Ernesto Castro Leal, Partidos e Programas. O campo partidário republicano português (19101926), op. cit., p. 151; Id., Manifestos, Estatutos e Programas Republicanos Portugueses (18731926). Antologia critica, op. cit., p. 208. 
Ernesto Castro Leal

República instaurada pela Revolução de 5 de outubro de 1910. 2. O Hino Nacional é A Portuguesa" (artigo 11\%).

Enviado el (Submission Date): 23/11/2016

Aceptado el (Acceptance Date): 15/05/2017 